\title{
Articles
}

\section{DFT Study for Azobenzene Crown Ether p-tert-Butylcalix[4]arene Complexed with Alkali Metal Ion}

\author{
Seong Jun Park and Jong-In Choe \\ Department of Chemistrv. Chung-Ang Lhwersit, Seoul 156-756. Korea. "E-mail: choejiäcau ac.kr \\ Received January 3,2008
}

\begin{abstract}
Stable molecular isomers were calculated for the azobenzene crown ether p-tert-butylcalix[4]arene (1) in the host and their alkali-metal-ion complexes. The structures of two distinct isomers (cis and trans) have been optimized using DFT B3LYP/6-31G(d,p) method. Trans isomer of 1 is found to be $11.69 \mathrm{kcal} / \mathrm{mol}$ more stable than cis analogue. For two different kinds of complexation mode, the alkali-metal-cation in the crown-ether moiety (exo) has much better complexation efficiency than in the benzene-rings (endo) pocket for both isomers of 1. Sodium ion has much better complexation efficiency than potassium ion in all kinds of conplexation mode with host 1 . The $\mathrm{Na}^{+}$complexation efficiency of the trans-complex (1) in the exo-binding mode is 8.24 $\mathrm{kcal} / \mathrm{mol}$ better than cis-exo analogue.
\end{abstract}

Key Words : Azobenzene calix[4]crown-ether. Complexation. Alkali metal ion. DFT B3LYP/6-3IG(d.p)

\section{Introduction}

Calix[4]crown ethers and related derivatives that have calix[4] arene $^{1}$ moiety as a subcyclic unit of crown ether are well studied. and their ion-binding properties toward alkali and alkaline earth metal cations have been characterized. ${ }^{2}$ Several different host compounds based on the calix-crown framework, including selective chromoionophores for alkali metal ion ${ }^{3}$ and double-calix-crowns, ${ }^{4}$ have been prepared and their interesting ionophoric properties were investigated.

1,3-Dimethyl ether of p-tert-butylcalix[-4]crown-5-ether has shown a surprisingly high $\mathrm{K}^{-} / \mathrm{Na}^{+}$selectivity in extraction, ${ }^{5}$ Recently, endo- or exo-complexation of calix[4]arene with alkali metal cations has been analyzed by HF. MP2 and DFT calculations. ${ }^{\circ}$

Azobenzenes have been incorporated into a number of supramolecular frameworks to produce ionophores for transports and photo-switchable receptors. ${ }^{7}$ They are interested in constructing a switchable molecular system which can selectively bind $\mathrm{Na}^{+}$or $\mathrm{K}^{-}$mimicking the biological $\mathrm{Na}^{-} / \mathrm{K}^{+}$ pump. ${ }^{7(b) i(t)}$

We have undertaken the relative binding affinity study of cone-shaped $p$-tert-butylcalix[4]aryl esters toward alkali metal cations focusing on the binding site of upper or lowerrim pocket of the host molecule using $D H^{\circ} \%$ calculation method. ${ }^{8}$ The B3LYP/6-3IG(d) calculation suggested that exo-complexation efficiency of alkali metal ion inside the cavity of lower rim of p-tert-butylcalix[4]aryl esters was much better than the endo-complexation inside the upper rint (four aromatic rings).

Recently, we have calculated the relative stabilities and stable structures of three different (cone, partial cone and

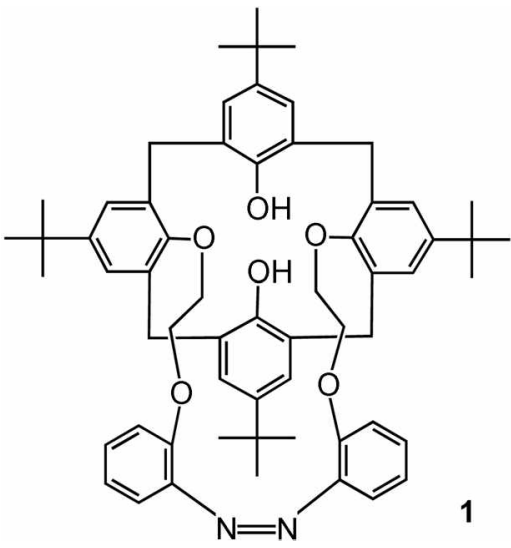

Scheme 1. Chemical drawing of the cis isomer of azobenzene crown ether $p$-tert-butylcalix[4]arene (1)

1.3-alternate) conformers for the 1,3-dialkyl ether of p-tent-

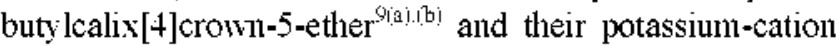
complexes using the B3LYP/6-3IG(d.p) method, and also for the conformers of 1.3-dimethyl ether of p-tert-butylcalix[4]arene crown ether bridged at the lower rim with pyridyl unit ${ }^{9 i c i}$ and their $\mathrm{K}^{-}$complexes. In their $D F /$ calculations, exo-complexes in crown cavity were $20-30 \mathrm{kcal} / \mathrm{mol}$ more stable than endo-analogues.

The first objective of this research is to determine the relative stability of cistrans isomers for the azobenzene crown ether $p$-tert-butylcalix[4]arene $(1)^{7(0)}$ by using $D F I$ $\mathrm{B} 3 \mathrm{LYP} / 6-3 \mathrm{IG}(\mathrm{d}$,p) calculations. The second objective is to compare the relative complexation efficiencies of their endo: exo alkali-metal-ion complexes of $\mathbf{1}$. And the third objective is to investigate the characteristics of cation-oxygen (nitrogen) and cation- $\pi$ interactions in the various complexes. 


\section{Computational Methods}

The initial isomers of azobenzene crown ether p-tertbutylcalix[4]crown-ether (1) were constructed by HyperChem ${ }^{11}$ In order to find optimized structures. we executed conformational search by simulated annealing method. ${ }^{11}$ The alkali-metal-ion complexes of 1 were fully re-optinized using DFT B3LYP/6-31G(d.p) methods to estimate the absolute and relative energies for the different complexes after semi-empirical AMI energy minimization. The DFT optimizations of cistrans isomers of host $\mathbf{1}$ and their alkalimetal-ion complexes of 1 by Gaussian $98^{12}$ were done with error limit of less than $0.01 \mathrm{kcal} / \mathrm{mol}\left(2 \times 10^{-6}\right.$ atomic unit (A.U.)) for each structure.

\section{Results and Discussion}

The DFT B3LYP/6-3IG $(\mathrm{d}, \mathrm{p})$ calculations without any constraint were carried out for two isomers of the host 1 . The DFT optimizations were also carried out for two kinds of complexation mode for each isomer: combining cis or troms isomer of 1 with an alkali metal ion in two different locations (the crown-ether (exo) or benzene-rings (endo) pocket) of 1 . Table 1 reports the B3LYP/6-31G(d.p) optimized energies of the cis and trans isomers of host (1) and four different complexes in two different binding modes.

The calculations suggest that trons isomer of $\mathbf{1}$ is found to be $11.69 \mathrm{kcal} / \mathrm{mol}$ more stable than cis analogue due to the steric hinderance of benzene rings.

When one compares the relative binding efficiencies of the complexes for the two different alkali metal ions in Table

Table 1. DFT B3LYP/6-3IG(d,p) Energies ${ }^{a}$ of Host (1) and Different Complexes with Alkali Metal Ions

\begin{tabular}{|c|c|c|c|}
\hline \multirow{2}{*}{\multicolumn{2}{|c|}{ B3LYP/6-31G(d,p) Calculated }} & \multicolumn{2}{|c|}{ Alkali metal guest } \\
\hline & & $\mathrm{Na}^{-}$ & $\mathrm{K}^{-}$ \\
\hline & & -162.0812 & -599.7250 \\
\hline Host Energy & Binding mode & \multicolumn{2}{|c|}{ Complex Energy } \\
\hline \multirow[t]{2}{*}{-2889.4454} & Host $\left(\mathbf{1}_{c i s}\right) \cdot$ Guest (exo) & -3051.6620 & -3489.2150 \\
\hline & Host $\left(\mathbf{1}_{c i r}\right) \cdot$ Guest (endo) & -3051.6217 & -3489.2491 \\
\hline \multirow[t]{3}{*}{-2889.4640} & Host $\left(\mathbf{1}_{\text {tr(T } m s}\right) *$ Guest (ero) & -3051.6936 & -3489.2612 \\
\hline & Host $\left(\mathbf{1}_{\text {trats }}\right) \cdot$ Guest (endo) & -3051.6584 & -3489.2749 \\
\hline & & \multicolumn{2}{|c|}{$\begin{array}{c}\text { Complexation Energy } \\
\left(\Delta E_{\text {complev }}\right)^{\prime}\end{array}$} \\
\hline \multicolumn{2}{|c|}{ Host $\left(1_{\text {crs }}\right) *$ Guest (exo $)$ complexation } & -84.91 & -27.95 \\
\hline \multicolumn{2}{|c|}{ Host $\left(1_{\text {crs }}\right) *$ Guest (ento $)$ complexation } & -59.62 & -49.35 \\
\hline \multicolumn{2}{|c|}{ Host $\left(1_{\text {tr(m) }}\right) \cdot($ Gluest (exo) complexation } & -93.05 & -45.28 \\
\hline \multicolumn{2}{|c|}{ Host $\left(1_{\text {trotrs }}\right) \cdot$ Guest (endo) complexation } & -70.98 & -53.86 \\
\hline
\end{tabular}

"Error limits in these calculations are about $2 \times 10^{-5}$ a.u. Units for the DFT energies of hosts. guests and complexes are reported in hartrees (a.u.), and units for the complexation energies are shown in kcalimol. converted using conversion factor $\mathrm{I}$ a.u. $=627.50955 \mathrm{kcal}$ mol. ${ }^{k}$ exo indicates crown-ether pocket binding, and endo means benzene-nings pocket mode. Host $\left(\mathbf{1}_{c i s}\right)$ means the cis isomer of 1 . Host $\left.\mathbf{1}_{\text {fnws }}\right)$ denotes the tranis isomer of $1 .{ }^{c} \Delta E_{\text {conplex }}$ is detined as the energy of the complex. minus the sum of the energies of the cation and the free ligand isomer.
1. the sodium ion has much better $(\sim 10-50 \mathrm{kcal} / \mathrm{mol})$ complexation efficiency than potassium ion in all four kinds of complexation mode with host 1 . Particularly. the exocomplexes show more prominent differences. For examples,

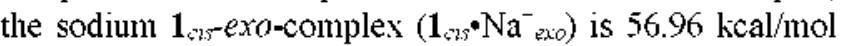
more efficient than the potassium analogue $\left(\mathbf{1}_{c: s} \mathrm{~K}^{+}{ }_{2 \times 0}\right)$, and the sodium $1_{\text {trans }}$ exo-complex $\left(1_{\text {trans }} \cdot \mathrm{Na}^{-}{ }^{-}{ }^{-}\right.$o $)$is $47.77 \mathrm{kcal} /$ mol better than the $\mathrm{K}^{+}$analogue $\left(\mathbf{1}_{\text {irann }} \cdot \mathrm{K}^{+} x_{0}\right)$. Primary reason of these huge differences in the binding efficiencies is the difference between the binding energies of $\mathrm{Na}^{-}$and $\mathrm{K}^{+}$per cation-oxy gen interaction (The cation-oxygen binding energies are reported as $-26.2\left(\mathrm{Na}^{-}\right)$and $-18.1\left(\mathrm{~K}^{-}\right) \mathrm{kcal} / \mathrm{mol}$ when a cation is binding to the $\mathrm{O}-\mathrm{H}$ group of phenol from the $\mathrm{HF} / 6-31 \mathrm{GG}(\mathrm{d}, \mathrm{p})$ calculation. $)^{14}$ Also. the conditions between calculation (in vacuum) and experimental environment $^{7(i)}$ (in solution) are different. One should note that in the gas phase it is natural that smaller cationic species such as $\mathrm{Na}^{-}$should have higher binding energy than larger $\mathrm{K}^{-}$ cation. However. in the presence of aqueous or polar solvents, a specific size of cations (rather than a smaller ion) would more selectively bind receptors. ${ }^{19}$

When one compares the relative stabilities of the complexes for the different guest positions in Table 1, the sodium ion in the crown-ether moiety $(e x o)$ has better $(-20 \mathrm{kcal} /$ mol) complexation efficiencies than in the benzene-rings (endo) pocket for both isomers of 1. For example. the trans exo-complex $\left(\mathbf{1}_{\text {trans }}{ }^{-} \mathrm{Na}^{+}{ }_{\text {exo }}\right)$ is $22.07 \mathrm{kcal} / \mathrm{mol}$ more stable than the trans endo-complex $\left(\mathbf{1}_{\text {rrans }}{ }^{*} \mathrm{Na}^{-}{ }_{\text {endo }}\right)$. and the cis exocomplex $\left(1_{i>5^{\circ}} \mathrm{Na}^{-}\right.$ cis endo-complex $\left(\mathbf{1}_{c i s}{ }^{\circ} \mathrm{Na}^{+}{ }^{+}{ }^{2} d\right.$ ) $)$. The weaker endo-complexation efficiencies are originated from the fewer number of electrostatic interactions of the sodium cation with ligand sites of oxygen and nitrogen atoms. However. the potassium ion in the benzene-rings (endo) pocket has better $(8-21 \mathrm{kcal} /$ mol) complexation efficiencies than in the crown-ether moiety $(e x o)$ for the isomers of $\mathbf{1}$. due to the fewer number of electrostatic interactions of the potassium ion in the exoposition.

The trans complexes of 1 are found to be more stable (about $8-17 \mathrm{kcal} / \mathrm{mol}$ ) than the cis analogues of 1 toward alkali metal ions. For example. the trans-complex $\left(\mathbf{1}_{\text {trans }}+\right.$ $\mathrm{Na}^{-}{ }_{20}$ ) is $8.14 \mathrm{kcal} / \mathrm{mol}$ more stable than the cis-complex

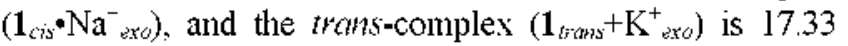
$\mathrm{kcal} / \mathrm{mol}$ more stable than the cis-complex $\left(\mathbf{1}_{c i s}{ }^{*} \mathrm{~K}^{+}{ }_{i x o}\right)$.

Figures l(a) and l(b) show the trans and cis isomers of the free host 1. respectively. Figures l(c) and l(d) display their (trons and cis) sodium complexes in exo-mode. and Figures $\mathrm{l}(\mathrm{e})$ and $\mathrm{l}(\mathrm{f})$ display their sodium complexes in endo-mode. respectively. When one sees the Figure 1(d) of the ciscomplex $\left(\mathbf{1}_{i j s} \mathrm{Na}^{+}{ }_{e v o}\right)$. all of the nitrogen and oxygen atoms in the crown-ether moiety are symmetrically converged to the center of the crown-ether ring due to the strong electrostatic attraction from sodium cation. The Figure l(e) of the trans endo-complex $\left(\mathbf{1}_{\text {rzuns }} \cdot \mathrm{Na}^{-}\right.$endede displays the cation- $\pi$ interactions from sodium cation to the $\pi$ electrons of two benzene rings whose planes are almost parallel to each other. When one sees the Figure $1(\mathrm{f})$ of the cis endo-complex 


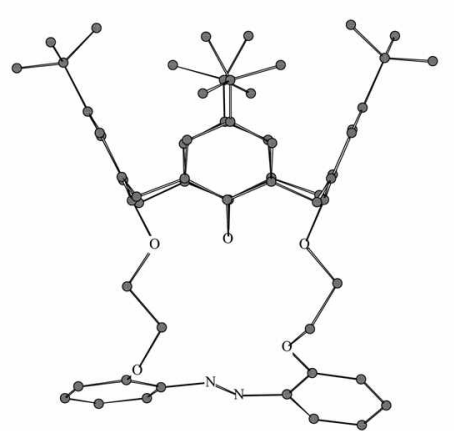

(a) $\mathbf{1}_{\text {trans }}$

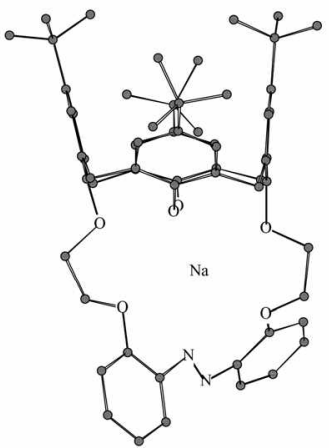

(c) $\mathbf{1}_{\text {trans }} \cdot \mathrm{Na}^{+}{ }_{\text {exo }}$

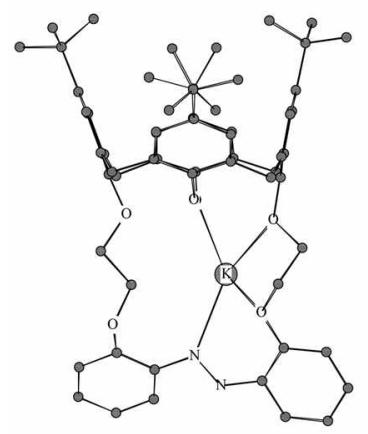

(g) $\mathbf{1}_{\text {trans }} \cdot \mathrm{K}_{\text {exo }}^{+}$

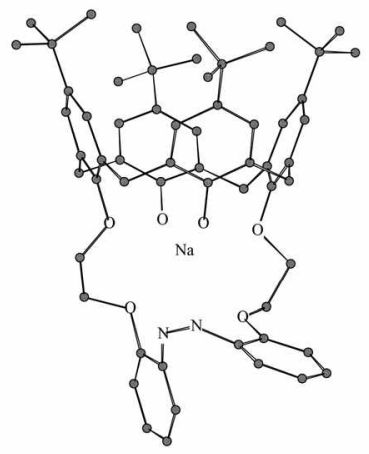

(d) $\mathbf{1}_{\text {cis }} \cdot \mathrm{Na}^{+}{ }_{\text {exo }}$

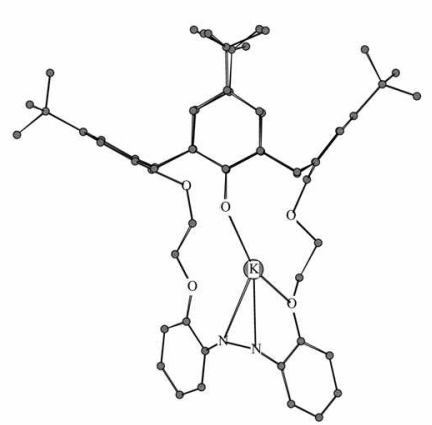

(h) $\mathbf{1}_{\text {cis }} \bullet \mathrm{K}_{\text {exo }}^{+}$

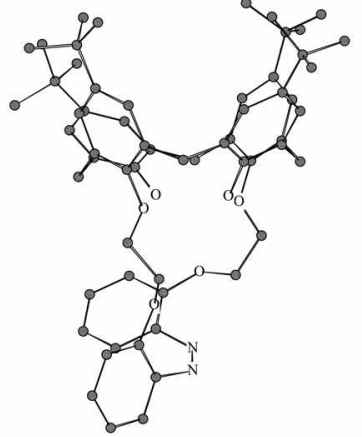

(b) $\boldsymbol{1}_{\text {cis }}$

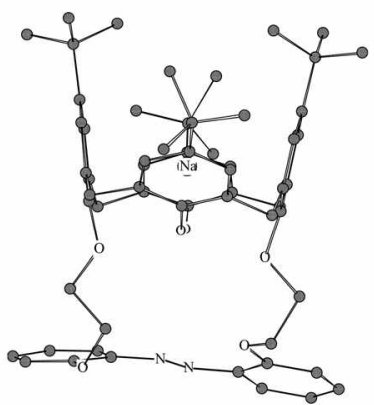

(e) $\mathbf{1}_{\text {trans }} \cdot \mathrm{Na}^{+}$endo

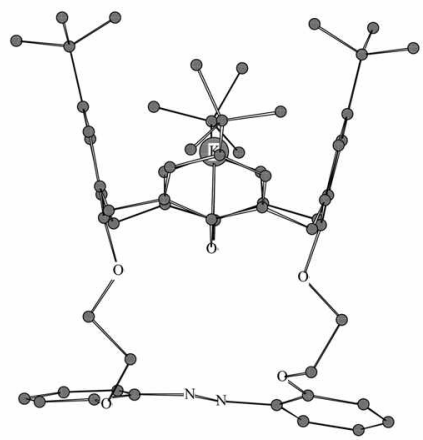

(i) $\mathbf{1}_{\text {trans }} \cdot \mathrm{K}_{\text {endo }}^{+}$

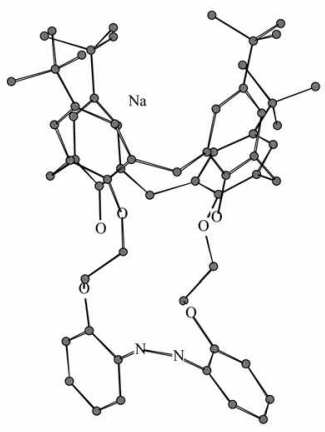

(f) $\mathbf{1}_{\text {cis }} \cdot \mathrm{Na}^{+}$endo

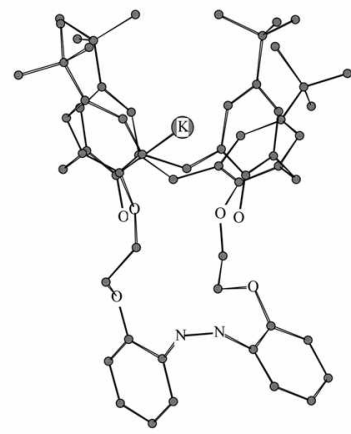

(j) $\mathbf{1}_{\text {cis }} \cdot \mathrm{K}_{\text {endo }}^{+}$

Figure 1. DFT calculated structures of trans and cis isomers of host 1 and their alkali-metal-ion complexes: (a) trons and (b) cis isomers of

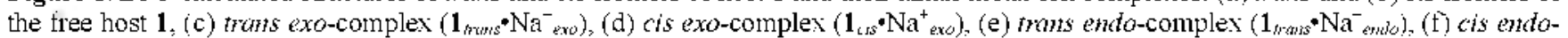

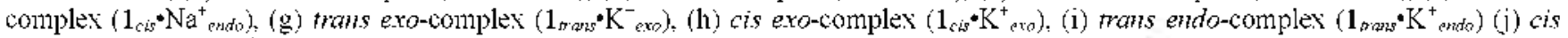
endo-complex $\left(1_{c i s}{ }^{+} \mathrm{K}_{\text {endo }}^{+}\right.$). Atoms that are within a certain distance (the bond proximate distance) from one another were automatically marked as bonded. ${ }^{13}$

$\left(\mathbf{1}_{\text {cis }} \bullet \mathrm{Na}^{-}\right.$encio), the sodium cation is shifted and more closely coordinated with two tert-butylbenzyl groups in the calix[4]arene moiety of the host due to the cation- $\pi$ interactions.

When one sees the Figure $\mathrm{I}(\mathrm{g})$ of the $t$ rams-complex $\left(1_{\text {truts }} \bullet \mathrm{K}^{+} \mathrm{vxo}\right)$, one of the nitrogen atoms and three of the oxygen atoms in the crown-ether moiety are converged to potassium cation due to the electrostatic attractions. When one sees the Figure $1(\mathrm{~h})$ of the cis-complex $\left(\mathbf{1}_{i s i} \bullet \mathrm{K}^{+}{ }^{*} \times 0\right)$, both of the nitrogen and some of oxygen atoms in the crown-ether moiety are converged to the center of the crown-ether ring due to the electrostatic attraction from potassium cation. The Figure l(i) of the trans endo-complex $\left(\mathbf{1}_{t r u m s} \cdot \mathrm{K}^{-}\right.$endio $)$displays the cation- $\pi$ interactions from potassium cation to the $\pi$ electrons of two benzene rings. where planes are not parallel as much as the Figure $\mathrm{l}(\mathrm{e})$ of the sodium-complex $\left(\mathbf{1}_{\text {rams }}\right.$. $\left.\mathrm{Na}^{-}{ }_{\text {into }}\right)$. When one sees the Fig. $\mathrm{l}(\mathrm{j})$ of the cis endocomplex $\left(\mathbf{1}_{c i s} \bullet \mathrm{K}^{+}\right.$endio $)$. the potassium cation is coordinated with all four tert-butylbenzyl groups in the calix[4]arene moiety of the host due to the bigger diameter of $\mathrm{K}^{-}(2.66 \AA)$ than $\mathrm{Na}^{+}(1.90 \AA)$.

The binding energies in the complexations of alkali metal cations with the host 1 are coming from cation- $\pi$ interactions in benzene rings and cation-oxy gen(nitrogen) interactions in crown-ether. The B3LYP/6-31G(d) calculations suggest that cation- $\pi$ binding energy is $-27.4 \mathrm{kcal} / \mathrm{mol}$ when $\mathrm{Na}^{-}$is binding to a benzene ring, and that cation- $\pi$ interaction 
Table 2. DFT Calculated Distances $(\AA)$ between Alkali Metal Cation and the Oxygen and Nitrogen Atoms of Host( 1 ) in the exo-Complex

\begin{tabular}{lcccc}
\hline & \multicolumn{2}{c}{$\mathrm{Na}^{+}$-Complex } & \multicolumn{2}{c}{$\mathrm{K}^{-}$-Complex } \\
\hline Distance from Cation & $1_{\text {tann }} \cdot \mathrm{Na}^{+}$ & $\mathbf{1}_{\text {ci: }} \cdot \mathrm{Na}^{-}$ & $1_{\text {tans }} \cdot \mathrm{K}^{+}$ & $\mathbf{1}_{\text {cil }} \cdot \mathrm{K}^{-}$ \\
\hline Ether-Oxygen (1) & 2.437 & 2.951 & 2.660 & 2.719 \\
Ether-Oxygen (2) & 2.490 & 2.920 & 2.914 & \\
Ether-Oxygen (3) & 2.700 & 2.774 & & \\
Ether-Oxygen (4) & & 2.865 & & \\
\hline Ave. Ether-Oxygen & 2.542 & 2.878 & 2.787 & 2.719 \\
\hline Hydroxy Oxygen (1) & 2.388 & 2.234 & 2.580 & 2.667 \\
Hydrosy Oxygen (2) & 2.589 & 2.277 & & \\
\hline Ave. Hydroxy Oxygen & 2.489 & 2.256 & 2.580 & 2.667 \\
\hline Nitrogen (1) & 2.622 & & 2.883 & 2.872 \\
Nitrogen (2) & & & & 2.889 \\
\hline
\end{tabular}

energy is $-17.3 \mathrm{kcal} / \mathrm{mol}$ for $\mathrm{K}^{-}$with the benzene. ${ }^{15}$ The $\mathrm{MP} 2 / 6-3 \mathrm{ll}+\mathrm{G}$ (d) calculations suggest that cation- $\pi$ interaction energy is $-18.7 \mathrm{kcal} / \mathrm{mol}$ for $\mathrm{K}^{+}$with the benzene ring of anisole, and that cation-oxygen binding energy is -19.4 $\mathrm{kcal} / \mathrm{mol}$ when $\mathrm{K}^{-}$is binding to the anisole oxy gen. ${ }^{16.17}$

To understand the cation-oxygen (nitrogen) interactions of the complexes of 1 , we have measured the distances from the alkali-metal-cation to the nitrogen and oxygen atoms of the host 1. (See Table 2).

An interesting fact deduced from the Table 2 is that the average distance $(2.256 \AA)$ between $\mathrm{Na}^{+}$and the hydroxy oxygen atoms of cis-isomer of 1 in exo-binding mode is much $(0.622 \AA)$ shorter than the average value $(2.878 \AA)$ between $\mathrm{Na}^{+}$and the crown-ether-oxygen atoms of the host. This suggest that the electrostatic attraction between $\mathrm{Na}^{+}$and the methoxy oxygen is much stronger, since the movement of hydroxy-oxygen atom is relatively free compared to the oxygen atoms of the crown-ether framework. BLYP/6$31 \mathrm{G}(\mathrm{d} . \mathrm{p})$ calculation suggests that the optimized binding distance between $\mathrm{Na}^{+}$and the oxygen atom of dimethylether is $2.197 \mathrm{~A}^{18}$

\section{Conclusion}

DFT B3LYP/6-3IG(d.p) calculations suggest that trons isomer of 1 is found to be $11.69 \mathrm{kcal} / \mathrm{mol}$ more stable than cis analogue. The alkali-metal-cation in the crown-ether moiety $(e x o)$ has much better $(\sim 20 \mathrm{kcal} / \mathrm{mol})$ complexation efficiency than in the benzene-rings (endo) pocket for both isomers of 1. Sodium ion has much better $(\sim 10-50 \mathrm{kcal} /$ mol) complexation efficiency than potassium ion in all kinds of complexation mode with host 1 . The $\mathrm{Na}^{+}$ complexation efficiency of the trans-complex (1) in the exo-binding mode is $8.25 \mathrm{kcal} / \mathrm{mol}$ better than cis-exo analogue. The number of cation-oxygen(nitrogen) interactions in crown-ether ring and hydroxy groups with alkali-metalcation was crucial to the stability of the cistrons isomers of $1 \cdot \mathrm{Na}^{+}$or $1 \cdot \mathrm{K}^{+}$complex
Acknowledgments. This research was supported by the Chung-Ang University research grants in 2007. The large portions of the computations were carried out with use of the computer facilities at the Research Center for Computational Science of The Okazaki National Research Institutes in Japan.

\section{References}

1. (a) Gutsche. C. D. Catixarnes: Royal Society of Chemistry: Cambridge. 1989. (b) Calixarenes: A Tersatile Class of Hacro culic Conpolmds: Vicens. J.: Böhmer. V. Eds.: Kluwer Academic Publishers: Dordrecht, The Netherlands, 1991. (c) Calixames 50 th Annersan: Conmemorative Iollme: Vicens, $\mathrm{J} ;$ Asfari, Z; Harrowfield, J. M. Eds.: Kluwer Academic Publishers: Dordrecht, The Netherlands. 1991. (e) Gutsche. C. D. Calizarenes Revisited. Royal Society of Chemistry: Cambridge. 1998. (f) Calixarenes in Action: Mandolitu. L.: Ungaro. R. Eds.: World Scientific Publishers Co: Singapore, 2007.

2. (a) Alfieri. C.: Dradi. E; Pochini, A.; Ungaro, R.; Andreetti, G. D. J. Chem. Soc. Chem Commm 1983. 1075. (b) Ghidini, E: Ugozzoli. F.: Ungaro. R.: Harkema. S.: El-Fadl. A. A.: Reinhoudt. D. N. J. Ant Chem. Soc. 1990. 112. 6979. (c) Nijenhuis. W. F.: Buiterhuis. E. G.: de Tong. F.: Sudhölter. E. J. R.: Reinhoudt. D. N. J. Am. Chem. Soc, 1991. 113, 7963. (d) Cation Binding by Macrocycles: Inone, Y.. Gokel, G. W.. Eds.: Marcel Dekiker: New York 1990. (e) Computational Approaches in Supramolecular Chemistry. Wiptf. G. Ed.: Kluwar Academic Publishers: Dordrecht. The Netherlands. 1994.

3. King. A. M.: Moore. C. P.: Sandanayake. K. R. A. S.: Sutherland. I. O. J. Chem Soc. Chem Conmun 1992, 582.

4. Asfari, Z: Weiss. J.: Pappalardo. S.: Vicens. J. Pure Appl. Chem. 1993. 65,585

5. (a) Dijkstra. P. J.: Brunink. J.: Bugge. K.-E.: Reinhoudt. D. N.: Harkema. S.: Ungaro. R.: Ugozzoli. F.: Ghidini. E. J. Am. Chen. Soc. 1989. 111. 7567. (b) Reinhoudt. D. N.: Dijkstra. P. J:: in1't Veld. P. J. A.; Bugge, K.-E.; Harkema, S.: Ungaro, R.: Ghidini. E. J. Am. Chem. Soc. 1987, 109. 4761. (c) Van Loon. J.-D.: Arduini. A.; Verboom, W: Ungaro, R: van Hummel, G. J.; Harkema, S.; Reinhoudt. D. N. Tetrahedron Lett. 1989. 30.2681.

6. Bernardino. R. J.: Cabral. C. Stiprantol. Chem. 2002. 1t. 57.

7. (a) Balzani. V: Scandola. F. Supranoleculor Photochentistm: Ellis Horwood: New York. 1991: pp 199-215 and references cited therein. (b) Kaim. W: Schwederski. B. Bioinorganic Chemistry: Inorganic Elements in the Chemistry of Life? John Wiley \& Sons: New York. 1994: pp 281-284. (c) Pipoosananakaton. B. Sukwattanasinitt. M.: Jaiboon. N.: Chaichit. N.: Tuttulani. T. Tetrahedron Lett. 2000. H. 9095. (d) Tan1. L. V.: Quan1g. D. I: Lee. M. H.: Kim, T. H.; Kim, H.: Kim, J. S. Bull. Kowam Chem. Soc. 2007, 28. 791. (e) Jeon. Y.-M:; Lim, T.-H; Kim, J.-G.: Kim. J.-S: Gong. M.S. Bull. Kowan Chem. Soc. 2007, 28.816

8. Choe. T.-I.: Oh. D.-S. Bull. Korean Chem. Soc. 2004. 25.847.

9. (a) Choe. T-I.: Chang. S.-K.: Lee. S.: Nanbu. S. J. Mol. Struct Theochem) 2005. 722. 117. (b) Choe. J.-I. Bull. Korean Chent Soc. 2007. 28, 235. (c) Choe, J.-I. Bull. Korean Chem. Soc, 2007. 28.2310 .

10. HyperChem Release 7.5; Hypereube. Ine: Waterloo, Ontario. Canada. 2002

11. Choe. J.-I.: Kim. K.: Chang. S.-K. Bull. Korem Chent. Soc. 2000. 21.465 .

12. Frisch. M. J.: Trucks. G. W; Scllegel. H. B.: Scuseria, G. E: Robb. M. A.; Cheeseman, J. R.: Zakrzewski, V. G.; Montgomery. J. A. Jr.; Stratmann. R. E.: Burant, J. C.; Dapprich. S.; Millam, J. M.: Daniels. A. D.: Kudin. K. N.: Strain. M. C.: Farkas. O.: Tomasi. T.: Barone. V.: Cossi. M.: Cammi. R.: Mennucei. B.: 
Pomelli. C.: Adamo. C.: Clifford. S.: Ochterski. J.: Petersson. G. A.: Avala. P. Y: Cui. Q.: Morokuma. K.: Malick. D. K.: Rabuck. A. D.: Raghavachari. K.: Foresman. J. B.: Cioslowski. J.: Ortiz. J. V.: Baboul A. G.: Stefanov. B. B.: Liu, G.: Liashenko. A.: Piskorz, P.: Komaromi. I: Gomperts R.: Martin, R. L.: Fox. D. J: Keith. T: Al-Laham, M. A.: Peng. C. Y: Nanayakikara. A: Challacombe. M.: Gill. P. M. W. Johnsen. B.: Chen. W.: Wong. M. W.: Andres. J. L.: Gonzalez. C.: Head-Gordon. M.: Replogle. E. S.: Pople. J. A. Gatssian 98. Revision A.11.3: Gaussian. Inc.: Pittslurgh. PA. 1998.

13. Chem 3D, Version 7.0: Cambridge Soft: Cambridge. MA. U.S.A. 2001.

14. Bemardino. R. I.: Cabral. C. Supramol Chem. 2002. 14. 57.

15. (a) Choi. H. S.: Suh. S. B.: Cho. S. J.: Kim. K. S. Proc Natl Acad
Sci. 1998. 95. 12094. (b) Marcias. A. T.: Noton. I. E.: Evanseck. J. D. J. Am. Chent Soc. 2003. 125. 2351

16. Nicholas. T. B.: Hay. B. P. J. Phis. Chem. A 1999. J03. 9815.

17. (a) Kim, K. S.: Tarakeshwar, P.: Lee, J. Y. Plys. Rev 2000. 100. 4145. (b) Kim, D: Hu, S.; Tarakeshwar. P.: Kim, K. S.: Lisy, J. M. J. Phus. Chem \& 2003, 107, 1228. (c) Lee. J. Y; Lee, S. J.: Choi. H. S.: Cho. S. J.: Kiml. K. S.: Ha. T. K. Chem. Pho Lett 1995. 232.67. (d) Kim. K. S.: Lee. T. Y.: Lee. S. J.: Ha. T. K.: Kim. D. H J. An Chem. Soc. 1994. 116.7399

18. Hay, P. B.: Nicholas, J. B.: Feller. D. J. Am. Chem Soc. $2000,122$. 10083 .

19. Choe. H. S.; Kim. D; Tarakeshwar, P.: Suh, S. B.: Kim, K. S. $d$. Org. Chen 2002. 67. 1848 